\title{
The Repertory of Prince Charles's (I) Company, 1608-1625
}

In recent years, studies by Rosalyn L. Knutson, Scott McMillin and Sally-Beth MacLean, Mary Bly and Andrew Gurr have demonstrated that reading the repertories of individual playing companies with the plays grouped together can yield fresh insights into the companies, their plays, and the general theatre history of the period concerned. ${ }^{1}$ The first stage in such a study is determining the plays that belonged to a given company at any given time, and although much of this work was carried out in the early to mid-twentieth century by E.K. Chambers and G.E. Bentley, and has been carried forward since by others (most recently by those named above), new discoveries can still be made. In the course of an ongoing study of the actor-playwright William Rowley, I have found evidence that may expand the known repertory of one of the companies he acted for: Prince Charles's Men, a Jacobean playing company that operated between 1608 and 1625. At present, twenty-six plays have been listed as belonging to this company, of which only eight have survived. However, fifteen more plays, eight of which are extant, may tentatively be added to the company's repertory if the available evidence is looked at in a new light. In this article I outline the history of Prince Charles's Men, and supply the evidence for possible additions to its repertory.

\section{The company}

The history of the company normally known as Prince Charles's Men ${ }^{2}$ can be divided into four periods. ${ }^{3}$ The first period $(1608-c 1614)$, covers the early years of the company, which was formed in 1608 , and by 1613 was probably performing at the Curtain in Shoreditch. The actor-playwright William Rowley appears to have been the leader from early on. The second period (1614-19) began in 1614 when the company merged with Lady Elizabeth's players, an adult public theatre troupe which had previously, in 1613, merged with a former children's company, the Children of the Queen's Revels. The merged company, which operated under Prince Charles's name, ${ }^{4}$ was involved 
in a project of Philip Henslowe's and Edward Alleyn's to build a new indoor playhouse at Porter's Hall, but the project fell through and the company performed instead at the Hope playhouse until the winter of 1616-17, eventually settling at the Red Bull, where it performed until 1619. During this period, the repertories of the former Children of the Queen's Revels and of the former Lady Elizabeth's Men may have become the property of Prince Charles's Men, as discussed below.

The company's third period (1619-22) began when Christopher Beeston, owner of the indoor Cockpit playhouse (also known as the Phoenix), brought in Prince Charles's Men to replace the Cockpit's former occupants, Queen Anne's Men. Prince Charles's Men stayed at the Cockpit until 1622. There is evidence that they were also using the outdoor Curtain at this time. ${ }^{5}$ The fourth and final period (1622-5) began when the company left the Cockpit in 1622, and performed at the Curtain for about a year before finding their way back to the Red Bull, where they seem to have been in place by July 1623. ${ }^{6}$ Also in 1623 , William Rowley left the company and began acting for the King's Men, by August at the latest. ${ }^{7}$

Bentley suggests that Christopher Beeston may have kept or bought some, if not all, of the company's playbooks in 1622, because the repertories of the companies that followed Prince Charles's players at the Cockpit contain plays which originally belonged to them. ${ }^{8}$ If so, Prince Charles's Men may have left the Cockpit with a depleted repertory.

When King James died in 1625, Prince Charles became king and took on the King's Men as his own company. This, along with a closure of the theatres due to plague, seems to have caused the dissolution of Prince Charles's Men.

\section{The repertory to date}

There have been three attempts at listing the repertory of Prince Charles's Men. E.K. Chambers (1923) lists the company's plays between 1608 and 1615; G.E. Bentley (1941) lists those from 1616 to 1625; and Andrew Gurr (1996) synthesises the lists of Chambers and Bentley, but makes some deliberate omissions (discussed below). In addition, some new attributions to the company have been provided by N.W. Bawcutt's 1996 publication of previously unknown transcripts of Henry Herbert's office-book. ${ }^{9}$

The plays attributed to Prince Charles's Men by these four studies may be listed in tabular form as follows. Information on dates, authorship and evidence for attribution derives from each play's entry in Bentley's The Jacobean and Caroline Stage unless otherwise indicated in the notes. Paren- 
thetical evidence for a play's authorship and date of composition is provided only when it derives from a different source than that noted in the second column. For completeness, all attributions made by the four studies are included, including some about which there is uncertainty and one that is very unlikely; these are marked accordingly and explanations are provided in the notes.

\begin{tabular}{|l|l|l|l|l|l|}
\hline & $\begin{array}{l}\text { Evidence for } \\
\text { attribution to } \\
\text { Prince Charles's } \\
\text { Men }\end{array}$ & Author & $\begin{array}{l}\text { Date of } \\
\text { composition }\end{array}$ & Date of \\
publication & Listed by & \\
\hline \hline $\begin{array}{l}\text { Hymen's } \\
\text { Holiday }\end{array}$ & $\begin{array}{l}\text { Revels accounts, } \\
\text { Shrove Monday } \\
\text { (24 February), } \\
1612\end{array}$ & $\begin{array}{l}\text { William } \\
\text { Rowley } \\
\text { (Henry } \\
\text { Herbert's } \\
\text { office-book, } \\
16 \\
\text { December, } \\
1633)\end{array}$ & $\begin{array}{l}1612 \text { or } \\
\text { earlier }\end{array}$ & Lost & $\begin{array}{l}\text { Chambers, } \\
\text { Gurr }\end{array}$ \\
\hline $\begin{array}{l}\text { The Knaves, } \\
\text { Parts 1 \& 21 }\end{array}$ & $\begin{array}{l}\text { Accounts of the } \\
\text { Treasurer of the } \\
\text { Chamber, 7 June } \\
1613\end{array}$ & Anon & $\begin{array}{l}1613 \text { or } \\
\text { earlier }\end{array}$ & Lost & Chambers \\
\hline $\begin{array}{l}\text { The Valiant } \\
\text { Welshman } \\
\text { (unlikely) }\end{array}$ & $\begin{array}{l}\text { Title page of 1615 } \\
\text { Quarto }\end{array}$ & 'R.A.' & $\begin{array}{l}1610-15 \\
\text { (literary } \\
\text { borrowings) }\end{array}$ & 1615 & Chambers \\
\hline $\begin{array}{l}\text { A Fair } \\
\text { Quarrel }\end{array}$ & $\begin{array}{l}\text { Title page of 1617 } \\
\text { Quarto }\end{array}$ & $\begin{array}{l}\text { Thomas } \\
\text { Middleton } \\
\text { and Rowley }\end{array}$ & $\begin{array}{l}\text { c1615-17 } \\
\text { (topical } \\
\text { subject } \\
\text { matter) }\end{array}$ & 1617 & $\begin{array}{l}\text { Bentley, } \\
\text { Gurr }\end{array}$ \\
\hline $\begin{array}{l}\text { The Younger } \\
\text { Brother }\end{array}$ & $\begin{array}{l}\text { Edward Alleyn's } \\
\text { diary, 3 October } \\
1617\end{array}$ & Anon & $\begin{array}{l}1617 \text { or } \\
\text { earlier }\end{array}$ & Lost & $\begin{array}{l}\text { Bentley, } \\
\text { Gurr }\end{array}$ \\
\hline $\begin{array}{l}\text { All's Lost by } \\
\text { Lust }\end{array}$ & $\begin{array}{l}\text { 1633 Quarto } \\
\text { states that Rowley } \\
\text { performed in it }\end{array}$ & $\begin{array}{l}\text { Rowley } \\
\text { (title page of } \\
\text { Quarto) }\end{array}$ & $\begin{array}{l}\text { c1619-20 } \\
\text { (presence } \\
\text { on Revels } \\
\text { Office } \\
\text { fragments) }\end{array}$ & 1633 & $\begin{array}{l}\text { Bentley, } \\
\text { Gurr }\end{array}$ \\
\hline
\end{tabular}




\begin{tabular}{|c|c|c|c|c|c|}
\hline $\begin{array}{l}\text { The World } \\
\text { Tossed at } \\
\text { Tennis }^{13}\end{array}$ & $\begin{array}{l}\text { Title page of } 1620 \\
\text { Quarto }\end{array}$ & $\begin{array}{l}\text { Middleton } \\
\text { and Rowley }\end{array}$ & $\begin{array}{l}1619-20 \\
\text { (topical } \\
\text { allusions) }\end{array}$ & 1620 & $\begin{array}{l}\text { Bentley, } \\
\text { Gurr }\end{array}$ \\
\hline $\begin{array}{l}\text { The Man in } \\
\text { the Moon } \\
\text { Drinks Claret }\end{array}$ & $\begin{array}{l}\text { Record of court } \\
\text { performance, } 27 \\
\text { December } 1621 \\
\text { (Inner Temple } \\
\text { Library MS. } 515 \text {, } \\
\text { no.7) }\end{array}$ & Anon & $\begin{array}{l}1621 \text { or } \\
\text { earlier } \\
\text { (Record of } \\
\text { court } \\
\text { performance) }\end{array}$ & Lost & $\begin{array}{l}\text { Bentley, } \\
\text { Gurr }\end{array}$ \\
\hline $\begin{array}{l}\text { The Witch of } \\
\text { Edmonton }\end{array}$ & $\begin{array}{l}\text { Record of court } \\
\text { performance, } 29 \\
\text { December } 1621 \\
\text { (Inner Temple } \\
\text { Library MS. 515, } \\
\text { no.7); also title } \\
\text { page of } 1658 \\
\text { Quarto }\end{array}$ & $\begin{array}{l}\text { Thomas } \\
\text { Dekker, } \\
\text { John Ford, } \\
\text { and Rowley } \\
\text { (title page of } \\
\text { Quarto) }\end{array}$ & $\begin{array}{l}1621 \\
\text { (publication } \\
\text { date of } \\
\text { source text) }\end{array}$ & 1658 & $\begin{array}{l}\text { Bentley, } \\
\text { Gurr }\end{array}$ \\
\hline $\begin{array}{l}\text { The Birth of } \\
\text { Merlin, or, } \\
\text { the Child } \\
\text { Hath Found } \\
\text { his Father } 14\end{array}$ & $\begin{array}{l}\text { Revels licence, } \\
1622\end{array}$ & $\begin{array}{l}\text { Rowley } \\
\text { (title page of } \\
\text { Quarto) }\end{array}$ & 1622 & 1662 & Bawcutt \\
\hline $\begin{array}{l}\text { The Dutch } \\
\text { Painter and } \\
\text { the French } \\
\text { Brawl }\end{array}$ & $\begin{array}{l}\text { Revels licence, } \\
10 \text { June } 1622\end{array}$ & Anon & 1622 & Lost & $\begin{array}{l}\text { Bentley, } \\
\text { Gurr }\end{array}$ \\
\hline $\begin{array}{l}\text { Love's Royal } \\
\text { Reward }^{15}\end{array}$ & $\begin{array}{l}\text { Revels licence, } \\
3 \text { October } 1622\end{array}$ & Anon & 1622 & Lost & Bawcutt \\
\hline $\begin{array}{l}\text { The Bellman } \\
\text { of Paris }\end{array}$ & $\begin{array}{l}\text { Revels licence, } \\
30 \text { July } 1623\end{array}$ & $\begin{array}{l}\text { Dekker and } \\
\text { John Day }\end{array}$ & 1623 & Lost & $\begin{array}{l}\text { Bentley, } \\
\text { Gurr }\end{array}$ \\
\hline $\begin{array}{l}\text { The Escapes } \\
\text { of Jupiter } \\
\text { (uncertain) }^{16}\end{array}$ & $\begin{array}{l}\text { Revels licence, } \\
26 \text { August } 1623\end{array}$ & $\begin{array}{l}\text { Thomas } \\
\text { Heywood } \\
\text { (handwriting } \\
\text { of MS.) }\end{array}$ & $\begin{array}{l}1623 \text { or } \\
\text { earlier }\end{array}$ & MS. only & Bawcutt \\
\hline $\begin{array}{l}\text { A Fault in } \\
\text { Friendship }\end{array}$ & $\begin{array}{l}\text { Revels licence, } \\
2 \text { October } 1623\end{array}$ & $\begin{array}{l}\text { Richard } \\
\text { Brome and } \\
\text { 'Young } \\
\text { Johnson' }\end{array}$ & 1623 & Lost & $\begin{array}{l}\text { Bentley, } \\
\text { Gurr }\end{array}$ \\
\hline
\end{tabular}




\begin{tabular}{|c|c|c|c|c|c|}
\hline $\begin{array}{l}\text { A Vow and a } \\
\text { Good One }\end{array}$ & $\begin{array}{l}\text { Revels list of court } \\
\text { performances, } \\
6 \text { January } 1623\end{array}$ & Anon & $\begin{array}{l}1623 \text { or } \\
\text { earlier }\end{array}$ & Lost & $\begin{array}{l}\text { Bentley, } \\
\text { Gurr }\end{array}$ \\
\hline The Madcap & $\begin{array}{l}\text { Revels licence, } \\
3 \text { May } 1624\end{array}$ & 'Barnes' & 1624 & Lost & $\begin{array}{l}\text { Bentley, } \\
\text { Gurr }\end{array}$ \\
\hline $\begin{array}{l}\text { The Honest } \\
\text { Citizen }^{17}\end{array}$ & $\begin{array}{l}\text { Revels licence, } \\
14 \text { July } 1624\end{array}$ & Day & 1624 & Lost & Bawcutt \\
\hline $\begin{array}{l}\text { A Wedding, } \\
\text { or, A Cure } \\
\text { for a } \\
\text { Cuckold }{ }^{18}\end{array}$ & $\begin{array}{l}\text { Revels licence, } \\
26 \text { July } 1624\end{array}$ & $\begin{array}{l}\text { John } \\
\text { Webster and } \\
\text { Rowley } \\
\text { (title page of } \\
\text { Quarto) }\end{array}$ & 1624 & 1661 & Bawcutt \\
\hline $\begin{array}{l}\text { The } \\
\text { Peaceable } \\
\text { King, or the } \\
\text { Lord Mendall }\end{array}$ & $\begin{array}{l}\text { Revels licence, } \\
19 \text { August } 1623\end{array}$ & Anon & $\begin{array}{l}\text { 1606-22 } \\
\text { (Revels } \\
\text { licence) }\end{array}$ & Lost & $\begin{array}{l}\text { Bentley, } \\
\text { Gurr }\end{array}$ \\
\hline $\begin{array}{l}\text { Fool Without } \\
\text { Book }^{19}\end{array}$ & $\begin{array}{l}\text { Revels licence, } \\
\text { c1623-4 }\end{array}$ & Rowley & $c 1623-4$ & Lost & Bawcutt \\
\hline $\begin{array}{l}\text { The Four } \\
\text { Sons of Amon }\end{array}$ & $\begin{array}{l}\text { Revels licence, } \\
6 \text { January } 1624\end{array}$ & Anon & $\begin{array}{l}1603 \text { or } \\
\text { earlier } \\
\text { (Henslowe's } \\
\text { diary and } \\
\text { Revels } \\
\text { licence) }\end{array}$ & Lost & Bentley \\
\hline The Parricide & $\begin{array}{l}\text { Revels licence, } \\
27 \text { May } 1624\end{array}$ & Anon & 1624 & Lost & $\begin{array}{l}\text { Bentley, } \\
\text { Gurr }\end{array}$ \\
\hline $\begin{array}{l}\text { The Fairy } \\
\text { Knight }\end{array}$ & $\begin{array}{l}\text { Revels licence, } \\
11 \text { June } 1624\end{array}$ & $\begin{array}{l}\text { Dekker and } \\
\text { Ford }\end{array}$ & 1624 & Lost & $\begin{array}{l}\text { Bentley, } \\
\text { Gurr }\end{array}$ \\
\hline $\begin{array}{l}\text { The Late } \\
\text { Murder in } \\
\text { Whitechapel, } \\
\text { or, Keep the } \\
\text { Widow } \\
\text { Waking }\end{array}$ & $\begin{array}{l}1625 \text { lawsuit } \\
\text { refers to } \\
\text { performances at } \\
\text { the Red Bull in } \\
1624\end{array}$ & $\begin{array}{l}\text { Dekker, } \\
\text { Ford, } \\
\text { Rowley and } \\
\text { Webster }\end{array}$ & 1624 & Lost & $\begin{array}{l}\text { Bentley, } \\
\text { Gurr }\end{array}$ \\
\hline $\begin{array}{l}\text { The Widow's } \\
\text { Prize }\end{array}$ & $\begin{array}{l}\text { Revels licence, } \\
25 \text { January } 1625\end{array}$ & Sampson & 1625 & Lost & $\begin{array}{l}\text { Bentley, } \\
\text { Gurr }\end{array}$ \\
\hline
\end{tabular}




\section{Repertory additions}

\section{(A) Rowley's authorship}

The repertory of Prince Charles's Men can be tentatively expanded once it is recognised that William Rowley's authorship of a play composed between 1608 and 1622 indicates that it was probably written for the company. Rowley was the company's most important playwright: the majority of their known surviving plays to date have been attributed at least in part to him. He was also a sharer in the company from 1608-23 and performed important duties such as receiving payments for court performances. ${ }^{20}$ Rowley was thus likely an 'attached professional playwright' (in the terminology used by Bentley), one of the dramatists who 'did not easily or frequently shift their company associations, but tended to work regularly for one troupe for long periods' ${ }^{21}$ Bentley demonstrates that, according to the available evidence, the attached dramatists of the Jacobean and Caroline companies normally wrote only for their own company. This rule may not always have been obeyed perfectly Thomas Heywood appears to have broken it once, and James Shirley and Philip Massinger each have one possible exception ${ }^{22}$ - but Bentley argues that the otherwise consistent records of the attached dramatists in writing for their own companies indicate that contracts of exclusivity between 'a settled company and its principal dramatist' seem to have 'become a convention in the reigns of James and Charles', and were rarely broken. ${ }^{23}$ It is thus likely that Rowley normally wrote for Prince Charles's Men until he left them in 1623.

Between 1608 and 1622, Rowley contributed to six plays that were performed by his own company (see table). He did also write The Changeling (with Middleton) in 1622, which was performed by Lady Elizabeth's Men, but Bentley has pointed out that this play was written during or shortly after the period in which Prince Charles's Men left the Cockpit theatre, and has thus hypothesized that Rowley wrote the play to fulfil a contract with Beeston. ${ }^{24}$ Since there are no other known plays written by Rowley for another company from 1608-22, we may posit that Rowley wrote exclusively for his own company during this period, except in the one instance of The Changeling, which may have been the result of a shift from playhouse to playhouse. The collaborative nature of most of Rowley's dramatic output is not a factor in this argument, since the collaborative plays involved have not been reliably associated with any other company.

Rowley became a freelance playwright in 1623, when he left Prince Charles's Men to join the King's. From 1623-4 he wrote two plays for his former company (see table); possibly one play for Lady Elizabeth's Men (The 
Spanish Gypsy, probably written by Dekker and Ford, perhaps with Middleton and Rowley, licensed 9 July 1623); and two plays for his new company, the King's Men (The Maid in the Mill, written with John Fletcher and licensed 29 August 1623; and The Bee, a lost play licensed 6 September 1624). ${ }^{25}$ This freelance writing may be explained by the fact that Rowley was not the principal dramatist of the King's Men: that position was taken by John Fletcher. Furthermore, Rowley was not a sharer in any company during this period; Bentley observes that he does not seem to have been sworn into the King's Men until $1625,{ }^{26}$ and until then was presumably working as a hired man. Rowley's output in 1623-4 does not therefore affect the argument for Rowley as an attached dramatist for Prince Charles's Men from 1608-22, and the likelihood of plays written before 1623 as all (except for The Changeling) or mostly belonging to Prince Charles's Men.

If we accept that Rowley was likely an 'attached dramatist' for Prince Charles's Men between 1608 and 1622, we can tentatively add to the company's repertory three extant plays that have been attributed to Rowley, are believed to date from this period and have not previously been reliably allocated to a playing company.

The first of these plays is A New Wonder, a Woman Never Vexed, attributed to Rowley on the title page of the 1633 Quarto. Most reference works date this play to 1625 , based on its use of a word supposedly topical to that year. However, George Cheatham has cast doubt on this topical allusion, and has argued that other allusions make 1611-c1614 a more likely date of composition. ${ }^{27}$ This new date means that $A$ New Wonder may be tentatively assigned to Prince Charles's company.

The second play is Wit at Several Weapons, which has never been convincingly assigned to a playing company. ${ }^{28}$ Although this play was first published in the 1647 Beaumont and Fletcher Folio, three stylistic analyses of its authorship have concluded that it was originally written by John Fletcher but then heavily revised by Middleton and Rowley in 1613-15. ${ }^{29}$ The revised version, at least, may thus be proposed as belonging to Prince Charles's Men. ${ }^{30}$

Finally, The Old Law was written by Middleton, Rowley, and possibly a third writer, in 1618-19. This play's textual history is complex, but none of the available theories about its origin conflicts with an attribution to Prince Charles's company. If, as the title page claims, the third writer was Philip Massinger, his contribution is likely to have been as a reviser when he was working for Beeston at the Cockpit in the 1620s (if the play was acquired by Beeston when Prince Charles's Men left the Cockpit). Alternatively, if Gary Taylor is correct that the third writer was Thomas Heywood, working as a 
collaborator, an attribution to the Prince's Men still remains plausible: while Heywood had formerly been a sharer-playwright like Rowley, his company, Queen Anne's Men, had folded in 1619, and Heywood was thus free from that date to write and/or to revise for another company. ${ }^{31}$

There is thus no evidence against The Old Law, A New Wonder and Wit at Several Weapons being in the repertory of Prince Charles's Men at some time between 1608 and 1622, and Rowley's authorship is suggestive of their presence there.

(B) The Revels Office fragments

In 1925, Frank Marcham discovered a number of manuscript fragments from the Revels Office, four of which contain lists of plays. The lists were dated by E.K. Chambers as 1619-20: he interpreted their contents as the titles of plays that were being considered for performance at court. ${ }^{32}$ Bentley used these lists for dating purposes throughout The Jacobean and Caroline Stage, but did not notice a significant division between the lists: three contain plays belonging to the King's Men, and one contains other, non-King's Men plays, some of which I have tentatively proposed as belonging to Prince Charles's Men, and others which have not been attributed at this time to any other company of the period.

There are two problems with Bentley's description of the fragments. First, he followed R.C. Bald in stating that the handwriting on Fragment D is that of Edward Knight, the bookholder of the King's Men, and thus in assuming that the fragments were a product of the King's Men. However, Robert Kean Turner has cast doubt on this assumption, citing Johan Gerritsen's unpublished opinion that Knight did not write them. ${ }^{33}$ Bentley also stated that most of the plays listed on the fragments were the property of the King's Men or are otherwise unknown, while acknowledging that plays from a few other companies are present. ${ }^{34}$ What he did not observe was that the non-King's Men plays are clustered on fragment $\mathrm{D}$, while all the plays on fragments $\mathrm{A}, \mathrm{B}$, and $\mathrm{C}$ can be linked with the King's Men (except one, Albumazar, a play performed at Cambridge University in 1615; nothing is known of its subsequent history). I suggest that many of the plays on fragment $\mathrm{D}$ can be linked with plays that belonged either to Prince Charles's Men, or to the Children of the Queen's Revels, one of their precursors. None of the plays on fragment D can be definitely linked to any other company.

Around 1614, Prince Charles's Men merged with Lady Elizabeth's Men, who had themselves recently merged with the former Children of the Queen's Revels. ${ }^{35}$ The Queen's Revels company had in turn been created from elements of the Blackfriars Boys in $1608 .{ }^{36}$ The end result of this sequence of 
mergers is that some or all of the playbooks of the Blackfriars Boys and Queen's Revels apparently became the property of Lady Elizabeth's company (evidence for this can be found in the fact that Lady Elizabeth's players performed Eastward Ho and The Dutch Courtesan - former Blackfriar's Boys plays - at court in 1613-14). ${ }^{37}$ Lady Elizabeth's repertory in 1614 thus combined old Blackfriars and Queen's Revels plays with more recent Lady Elizabeth's plays such as A Chaste Maid in Cheapside (1613) and Bartholomew Fair (1614). ${ }^{38}$ When Lady Elizabeth's Men subsequently merged with Prince Charles's Men, it is likely that this mixed repertory became in part or entirely the property of the new, combined company of Prince Charles.

It must be acknowledged that not every Blackfriars or Queen's Revels play became the property of Prince Charles's Men. Beaumont and Fletcher's The Coxcomb, performed at court in 1612 by the Queen's Revels, was subsequently performed by Lady Elizabeth's Men, but in 1622 was being performed by the King's company. ${ }^{39}$ However, The Coxcomb is the only known exception; all other plays of the Blackfriars and Queen's Revels which turn up after the merger period and before the dissolution of Prince Charles's Men in 1625 belonged to Lady Elizabeth's Men. Furthermore, fragment D suggests that a number of the Blackfriars and Queen's Revels plays remained with Prince Charles's Men.

The plays on fragment $\mathrm{D}$ are - where their companies are known or have been tentatively assigned to Prince Charles's Men above - a mixture of Prince Charles's, Queen's Revels and Blackfriars plays. It is thus exactly what we would expect the repertory of Prince Charles's Men to look like by 1619 .

Fragment $\mathrm{D}$ reads as follows (square brackets indicate deletions).

\author{
Witt at \\ the Bridegr ... \\ An ould Lawe . a ..... \\ Henrye the vna .. \\ A ffaire Quarrell \\ ...r: - All's Lost by Lust \\ the Cittye: \\ the House is Haunte ... \\ Looke to the Ladye: \\ Titus, and Vespatian, \\ age - A Turkes too good for hi ... \\ the scilent woeman: \\ [the Dutch Curtizan:] \\ Trage - D'Ambois \\ [A woemans A wethercock $]^{40}$
}


On the fragment, two Rowley plays that definitely belonged to Prince Charles's Men, A Fair Quarrel and All's Lost by Lust, appear next to each other, while close by them are An Old Law and 'Witt at', which probably refers to Wit at Several Weapons since no other known play begins with those words. ${ }^{41}$ As we have seen, Rowley's authorship of the two latter plays suggests that they too likely belonged to Prince Charles's Men. With the other three fragments containing only King's company plays, the possibility is thus raised that fragment D lists only plays in the repertory of Prince Charles's company, and this hypothesis is supported by the fact that two plays on fragment $\mathrm{D}$, The Silent Woman (i.e. Jonson's Epicoene) and Field's A Woman is a Weathercock were originally performed by the Children of the Queen's Revels; one, Marston's The Dutch Courtesan, was originally performed by the Blackfriars Boys; and one other, Chapman's Bussy D'Ambois, was probably possessed by the Blackfriars Boys. ${ }^{42}$

The remaining five plays on the fragment have not been attributed previously to any company, since they are essentially unknown. The Bridgr [...] Henry the vna[...], The Cittye, The House is Haunted, and A Turk's Too Good for Him are all known only from this list. Look to the Lady, Chambers noted, is the title of a lost play by James Shirley, but both he and Bentley do not consider Shirley's career to have begun this early, so it is probably a different play of the same name, about which nothing is known. Titus and Vespatian is the title of a play performed by Strange's Men in 1592-3: Bentley and Chambers both found the presence of such an old play in the list puzzling, and suggested that it could be a new version of the story. ${ }^{43}$ These five unknown plays therefore do not conflict with the theory that fragment D contains only Prince Charles's Men plays.

Fragment D thus contains the names of both definite and likely Prince Charles's Men plays, and of no plays that can plausibly be attributed to other companies. Given that fragments A-C do not mix plays from different companies, very possibly fragment $\mathrm{D}$ does not do so either, and the unattributed, unknown plays on D belong to Prince Charles's Men.

One final play that can be tentatively attributed to Prince Charles's Men is not a Rowley play or one from fragment D: this is Nathan Field's Amends for Ladies. The title page of the 1618 Quarto says it was performed by both Prince Charles's Men and the Lady Elizabeth's. Gurr explains this title page as indicating 'either a joint performance or a series of performances that started under the Lady Elizabeth's name, and then took the name of Prince Charles's'. ${ }^{44}$ Since Lady Elizabeth's Men merged with Prince Charles's Men 
in or around 1614, the title page presumably describes an original Lady Elizabeth's play coming into Prince Charles's repertory after the merger.

\section{Conclusion}

If we accept that a play written by William Rowley between 1608 and 1622 is likely to have belonged to Prince Charles's Men, and if we further accept that Revels Office fragment D lists part of the company's repertory, then it is possible, beyond the eight extant plays already attributed by scholars to Prince Charles's Men, to attribute a further eight extant plays to them: A New Wonder, Wit at Several Weapons, The Old Law, Epicoene, The Dutch Courtesan, A Woman is a Weathercock, Bussy D'Ambois and Amends for Ladies. Seven additional lost plays may also be attributed to them.

This large repertory may have been lost after 1622 if Christopher Beeston did indeed keep or buy much of Prince Charles's Men's repertory at that time. Still, if my arguments are accepted as plausible, we now have a better perspective on the likely identity of Prince Charles's Men, via their repertory, from 1614 to 1622 . The most remarkable difference is the large number of satirical city comedies we now see as possibly having been in its repertory during the second and third periods of its history.

\section{Notes}

I am extremely grateful to Anne Lancashire and Marion O'Connor whose generous advice was invaluable during the completion of this article. I am grateful also to Helen Ostovich and the anonymous readers of Early Theatre for their encouragement and support.

1 Roslyn Lander Knutson, The Repertory of Shakespeare's Company, 1594-1613 (Fayetteville, 1991); Scott McMillin and Sally-Beth MacLean, The Queen's Men and their Plays (Cambridge, 1998); Mary Bly, Queer Virgins and Virgin Queans on the Early Modern Stage (Oxford, 2000); Andrew Gurr, The Shakespeare Company, 1594-1642 (Cambridge, 2004). Lucy Munro, Children of the Queen's Revels: A Jacobean Theatre Repertory (Cambridge, 2005) unfortunately came out too late for me to acquire and consult it for this essay.

2 It was known as the Duke of York's company or the Duke of Albany's company until 1612, using the then titles of its patron, the young Prince Charles. When Prince Henry died in 1612, Charles's company became known as Prince 
Charles's Men, commonly shortened to 'the Prince's Men'. Previously, the name 'Prince's Men' had referred to Prince Henry's company, and confusion between these two companies can sometimes arise. In addition, theatre historians may refer to the company as Prince Charles's (I) Men in order to distinguish it from a later company whose patron was the future Charles II.

3 Unless otherwise stated, the information in this section is taken from Andrew Gurr, The Shakespearian Playing Companies (Oxford, 1996), 394-412.

4 The touring sections of the companies continued to work separately under their original names (Gurr, Shakespearian Playing Companies, 401).

5 G.E. Bentley, Jacobean and Caroline Stage, (Oxford, 1941-68), 6:134-6.

6 Bentley, Jacobean and Caroline Stage, 1:205-9, provides a more detailed explanation of this stage of the company's career than does Gurr.

7 Bentley, Jacobean and Caroline Stage, 2:556-7.

8 Bentley, Jacobean and Caroline Stage, 2:364. The Prince Charles's plays that later appear in the repertories of Lady Elizabeth's Men, Queen Henrietta's Men, and the King and Queen's Young Company are All's Lost by Lust, The Witch of Edmonton, Hymen's Holiday, and A Fair Quarrel. In addition, a play called The World may be The World Tossed at Tennis (Bentley, Jacobean and Caroline Stage, 1:196, 251-6, 340-2). An alternative explanation is that Beeston bought the playbooks of Prince Charles's Men after their breakup in 1625. However, since All's Lost by Lust, originally a Prince Charles's play, is known to have been performed by Lady Elizabeth's Men, and since the latter company also broke up in 1625, it seems clear that Beeston held onto at least one play in 1622: it is thus possible that the other plays that later appeared at his theatre were obtained at the same time.

9 E.K. Chambers, Elizabethan Stage, (Oxford, 1923), 2:244; Bentley, Jacobean and Caroline Stage, 1:214-17; Gurr, Shakespearian Playing Companies, 408-9; N.W. Bawcutt, The Control and Censorship of Caroline Drama: The Records of Sir Henry Herbert, Master of the Revels 1623-73 (Oxford, 1996), passim. For Bawcutt's description of finding the previously unknown Herbert records, see 'New Entries from the Office-Book of Sir Henry Herbert', in English Literary Renaissance 26 (1996), 155-66.

10 For a full transcription of the relevant Revels accounts entry, see W.R. Streitberger (ed), Jacobean and Caroline Revels Accounts, 1603-1642, Malone Society Collections, Vol XIII (Oxford, 1986), 48-9.

11 Information on The Knaves is from Chambers, Elizabethan Stage, 2:244, 4:180. Note that Chambers' transcription of the date of performance from the Treasurer's Accounts is inaccurate (reading 10 March for 5 March): see David 
Cook and F.P. Wilson (eds), Dramatic Records in the Declared Accounts of the Treasurer of the Chamber, 1558-1642, Malone Society Collections, Vol. VI (Oxford, 1961 [1962]), 54-5. Gurr omits The Knaves 1 and 2 from his list, attributing them instead to Prince Henry's Men (The Shakespearian Playing Companies, 255). However, it is certain that The Knaves belonged to Prince Charles's Men because Rowley received the payment for them when they were performed at court in 1613 (Cook and Wilson, Dramatic Records, 54-5).

12 Information on this play is from Chambers, Elizabethan Stage, 2:244, 4:51. Chambers' attribution is based on the 1615 Quarto which states that 'the Prince of Wales his servants' performed the play. However, as R.A. Foakes has pointed out, Prince Charles did not become Prince of Wales until November, 1616, and the title page thus more likely refers to a performance by Prince Henry's Men; see Illustrations of the English Stage, 1580-1642 (London, 1985), 165. This is presumably why Gurr does not include the play in his list.

13 This text was described as a 'Courtly Masque' when published. Masques were not normally part of a company's repertory. However, the court performance of The World Tossed at Tennis was cancelled and it was performed at public theatres instead; it should thus be regarded as part of the company's repertory (Bentley, Jacobean and Caroline Stage, 4: 908-9).

14 Information on this play is from Bawcutt, Control and Censorship, 136, except for the authorship attribution. The 1661 Quarto attributes the play to Rowley and Shakespeare. The latter's presence has rarely been accepted and Bawcutt's recent discovery that the play was described as 'New' in 1622 further diminishes the possibility. Joanna Udall's scholarly edition of the play accepts Rowley's authorship but is unable to say whether he worked with a collaborator; see A Critical, Old-Spelling Edition of 'The Birth of Merlin' (Q1662) (London, 1991), 23-31.

15 Information on this play is from Bawcutt, Control and Censorship, 138.

16 Information on the date of The Escapes of Jupiter is from Bawcutt, Control and Censorship, 143. Its presence in this table requires explanation: on 26 August 1623, Herbert described it as 'an olde Playe' that had been 'taken from the Cockpitt upon the remove of some of the sharers $\&$ because they had payde their parts', an action that 'was not complained of by the company of the Cockpitt'. If Bawcutt is correct in suggesting that 'the sharers' refers to Prince Charles's Men after they had left the Cockpit, the entry seems to show that The Escapes of Jupiter was part of their repertory.

17 Information on this play is from Bawcutt, Control and Censorship, 153. 
18 Information on this play's title, date and license is from Bawcutt, Control and Censorship, 153.

19 Information on this play is from Bawcutt, Control and Censorship, 211.

20 Bentley, Jacobean and Caroline Stage, 2:555-6.

21 G.E. Bentley, The Profession of Dramatist in Shakespeare's Time (Princeton, 1971), 30.

22 On Heywood, see Neil Carson, 'Collaborative Playwriting: The Chettle, Dekker, Heywood Syndicate', Theatre Research International 14 (1989), 18-19. On Shirley and Massinger, see Bentley, Profession of Dramatist, 116-17.

23 Bentley, Profession of Dramatist, 120.

24 Bentley, Jacobean and Caroline Stage, 5:1016.

25 The title pages of the 1653 and 1661 quarto imprints of The Spanish Gypsy attribute it to Middleton and Rowley, but several stylistic analyses have suggested that the main authors were in fact Dekker and Ford; however, the additional presence of Middleton and Rowley has not been entirely dismissed by any study. The debate is summarized by Gary Taylor, 'Thomas Middleton, The Spanish Gypsy, and Collaborative Authorship', in Brian Boyd, ed, Words That Count: Essays on Early Modern Authorship in Honor of MacDonald P. Jackson (Newark, 2004): Taylor argues that the play's linguistic texture is best explained as a Middleton/Rowley/Dekker/Ford collaboration (257). On The Maid in the Mill, see Bentley, Jacobean and Caroline Stage, 3:377. On The Bee, see Bawcutt, Control and Censorship, 155.

26 Bentley, Jacobean and Caroline Stage, 2:556.

27 George Cheatham, ed. 'A New Wonder, a Woman Never Vexed': An Old-Spelling, Critical Edition (New York, 1993), 19-23. The 1625 date was suggested by I.A. Shapiro, 'Tityre-tu and the Date of William Rowley's Woman Never Vext', Review of English Studies ns 11 (1960), 55-6.

28 Gurr, Shakespearian Playing Companies, 373, assigns it to the King's Men without explanation.

29 Cyrus Hoy, 'The Shares of Fletcher and his Collaborators in the Beaumont and Fletcher Canon (V)', Studies in Bibliography 13 (1960), 89-92; David J. Lake, The Canon of Thomas Middleton's Plays (Cambridge, 1975), 198-214; MacDonald P. Jackson, Studies in Attribution: Middleton and Shakespeare (Salzburg, 1979), 125-7. The date of the revision derives from the play's references to the New River, completed in September 1613. Lake claims that any date after 1613 is impossible because the river would no longer have been topical (198), but its novelty value could surely have lasted longer than a few months. Jackson prefers a less specific date of 1613-15. 
30 The revision of Wit at Several Weapons may be explained if, as I propose later in this article, Prince Charles's Men inherited some of the playbooks of the Children of the Queen's Revels. Since Fletcher frequently wrote for the Queen's Revels during his early career (Gordon McMullan, The Politics of Unease in the Plays of John Fletcher [Amherst, 1994], 13), a likely explanation of the play's genesis is that Fletcher wrote the original version for the Queen's Revels; in 1613 the playbook shifted to Lady Elizabeth's Men; and around 1614 or so, following the merger of Lady Elizabeth's Men with the Prince's Men, Middleton and Rowley undertook a revision of the play.

31 Information in this paragraph is from Gary Taylor, 'Middleton, Rowley - and Heywood: The Old Law and New Attribution Technologies', Papers of the Bibliographical Society of America 96 (2002), 167-70, 210-13.

32 For facsimiles and transcripts, see Frank Marcham, The King's Office of the Revels 1610-1622: Fragments of Documents in the Department of Manuscripts, British Museum (London: Frank Marcham, 1925) 10-15, 32-3. On the date and purpose of the fragments, see E.K. Chambers, review of ibid., Review of English Studies 1 (1925), 483-4.

33 Bentley, Jacobean and Caroline Stage, 5.1309 etpassim; R.C. Bald (ed), Hengist, King of Kent; or The Mayor of Queenborough (New York, 1938), xxi n 1; Robert Kean Turner (ed), 'Wit at Several Weapons', The Dramatic Works in the Beaumont and Fletcher Canon, Fredson Bowers (ed) (Cambridge, 1966-96), 7:308 n 6.

34 Bentley, Jacobean and Caroline Stage, 5:1309, 1406 et passim.

35 On the latter merger, see Gurr, Shakespearian Playing Companies, 398-9.

36 Gurr treats the Queen's Revels as essentially a re-formed version of the Blackfriars Boys (354-7). Richard Dutton has recently argued against assuming continuity between the two companies, preferring to describe the Queen's Revels as a new company drawn from elements of the Blackfriars Boys and another company, the Children of the King's Revels; see 'The Revels Office and the Boy Companies, 1600-13: New Perspectives', English Literary Renaissance 32 (2002), 339-42. Dutton's argument does not of course preclude the plays of the Blackfriars Boys being inherited by the Children of the Queen's Revels during the merger that formed it.

37 Cook and Wilson, Dramatic Records, 58-9.

38 Gurr, Shakespearian Playing Companies, 412.

39 Chambers, Elizabethan Stage, 3:223.

40 Marcham, King's Office of the Revels, 15.

41 Turner, 'Wit at Several Weapons', 302. 
42 On the dates and auspices of the first three plays, see Chambers, Elizabethan Stage, 3:313, 369-71, 430-1 (Chambers sometimes refers to the Queen's Revels company as 'the Children of Whitefriars'). Bussy D'Ambois was originally performed by the Children of Paul's, but the Blackfriars Boys probably acquired the play when the Children of Paul's disbanded in 1606: there is evidence that it was originally written for the Blackfriars but was stolen, and also that Nathan Field, of Lady Elizabeth's Men, became famous in the role of Bussy (Chambers, Elizabethan Stage, 3:253-4). Although it has been conjectured that Nathan Field took the play with him when he left the Prince Charles's Men for the King's in 1616 (see Nicholas Brooke, ed. Bussy D'Ambois [London: Methuen, 1964], liv), there is no strong evidence for this: while the King's Men revived the play in 1634, they could have acquired it long after Prince Charles's Men had disbanded.

43 On Look to the Lady, see Chambers, review of Marcham, 482-3; Bentley, Jacobean and Caroline Stage, 5:1128. On Titus and Vespasian, see Chambers, review of Marcham, 483; Bentley, Jacobean and Caroline Stage, 5:1421.

44 Gurr, Shakespearian Playing Companies, 401. 